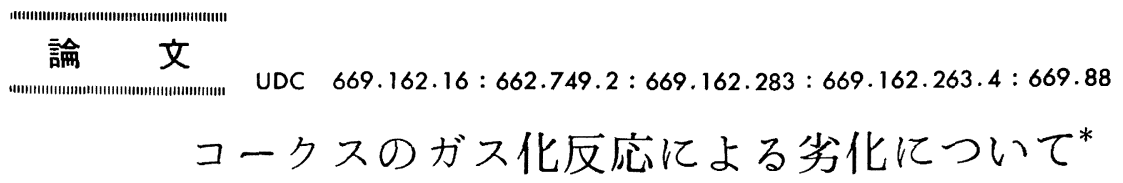

張 東 植**. 館充***

\title{
Degradation of Coke due to Gasification
}

Tonshik Ghang and Mitsuru TATE

Synopsis:

Experiments on the degradation of cokes due to gasification with $\mathrm{CO}_{2}$ under the presence of ore and alkali were carried out.

Following results were obtained:

1) The degree of gasification increases with the increase of blending ratio of ore, and this brings about the corresponding decrease of strength.

2) The presence of alkali increases the chemical reaction rate by its catalytic action, and results in the localization of reaction sphere to the surface zone of a coke particle. It also results in the conservation of a sound core and in the apparent alleviation of the degradation of the particle as a whole (compared to that without alkali).

3) Coke B made from a specially inferior coal blend shows a steep fall of strength after reaction at a overall gasification ratio of $10 \%$ or so, and this feature becomes remarkable under the presence of alkali, while the strength of coke A made from an ordinary coal blend decreases gradually as the degree of reaction increases.

The difference between coke A and B seems to suggest that "critical degree of gasification", at which it may disintegrate, of the latter is essentially smaller than that of the former. It also seems to suggest that the remarkable degradation of coke B probable at some high degree of reaction may be at least one of the reason of its severe disintegration in the experimental blast furnace (in the 26th run).

\section{1. 緒}

言

東京大学生産技術研究所の試験高炉第 26 次操業に徖 いて劣質コークスの使用により, 顕著な通気, 荷下り異 常を経験した1).

吹卸し後, 炉内残留コークス試料の諸調査結果に上れ ば，異常炉況を招いた原因は劣質コークスの高温域にお ける細粒化にあり,この細粒化の要因としてアルカリ成 分のコークスーの吸着による直接的な劣化，ならびにガ ス化 (ソリューション・ロス) 反応が推察された.

別報2)では，とくにアルカリ吸着によるコークスの劣 化に焦点をしぼり，この側面からコークスの細粒化要因 を検討したが，第 $25 \cdot 26$ 次操業の劣質コークスの著し い劣化が，この要因にあったと考兄らる結果は兄られな かった.

本報では，他方のガス化反応に焦点をしばり，この側 面から反応によるコークスの劣化，これに及ぼすューク
ス-鉱石混合層の影響, 同じくアルカリの触媒作用の影響 などを調查し，これらの結果にもとずき，コークスの細 粒化要因を検討した.

なお， 反応の進行様式の違いがュークスの劣化に及ぼ す効果についてる調査し，一定の知見を得たので報告す る.

\section{2. 実験装置および実験条件}

\section{$2 \cdot 1$ 実験装置と方法}

実験炉は別報2) に示した第 4 段階の炬と同一のものを 使用した。

反応管は 2 インチのステンレス製であり，アルカリ添 加時はその直下 $40 \mathrm{~mm}$ の位置にアルカリ受血にのせて 吊した、なおこの装置は, 反応ガス拉よびアルカリ蒸気 はすべてコークス層内を流通するよらにした。

試料は所定量を反応管内に充埧層で装入し，これを $\mathrm{N}_{2}$ キャリアーガスを微量流しながら所定温度に加熱し

* 昭和 51 年 10 月, 52 年, 10 月本会講演大会にて発表 昭和 53 年 6 月 15 日受付 (Received June 15, 1978)

** 東京大学生産技術研究所 (Institute of Industrial Science, The University of Tokyo, 1-8 Yayoi-cho Chiba 280)

*** 東京大学生産技術研究所 工博 (Institute of Industrial Science, The University of Tokyo) 
Table 1. Experimental conditions.

\begin{tabular}{|c|c|c|c|c|c|c|c|c|}
\hline & \multicolumn{2}{|c|}{$\begin{array}{l}\text { Item of } \\
\text { investigation }\end{array}$} & $\begin{array}{l}\text { Coke size } \\
\quad(\mathrm{mm})\end{array}$ & $\begin{array}{c}\text { Sample weight } \\
(\mathrm{g})\end{array}$ & $\begin{array}{l}\text { Temperature } \\
\left({ }^{\circ} \mathrm{C}\right)\end{array}$ & $\begin{array}{c}\text { Reaction gas } \\
(1 / \mathrm{mm})\end{array}$ & $\begin{array}{c}\text { Reaction time } \\
\text { (h) }\end{array}$ & $\begin{array}{l}\text { Alkali addi- } \\
\text { tion }(\mathrm{g})\end{array}$ \\
\hline \multirow{3}{*}{ 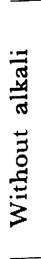 } & \multirow{2}{*}{$\stackrel{\stackrel{*}{*}}{\stackrel{*}{\Xi}}$} & Coke only & $9.52 \sim 12.7$ & $130 \sim 250$ & $900 \sim 1100$ & $\mid \begin{array}{c}\mathrm{N}_{2}+\mathrm{CO}_{2}: 2 \sim 6 \\
\mathrm{CO}_{2}: 25,50,75,100 \%\end{array}$ & $0.5 \sim 1.5$ & - \\
\hline & & $\begin{array}{l}\text { Presence of } \\
\text { ore }\end{array}$ & " & $\begin{array}{c}125 \\
(0 / c: 1,2,3)\end{array}$ & 1000 & $\begin{array}{c}\mathrm{N}_{2}+\mathrm{CO}_{2}: 4 \\
\mathrm{CO}_{2}: 25,50,75,100 \%\end{array}$ & 0.5 & - \\
\hline & & MSI*** & " & $40(50) *$ & $\begin{array}{c}1050 \\
(1000,1100)^{*}\end{array}$ & $\begin{array}{l}\mathrm{N}_{2}+\mathrm{CO}_{2}: 4 \\
\mathrm{CO}_{2}: 75 \%\end{array}$ & $1 \sim 2$ & - \\
\hline \multirow{3}{*}{ 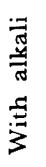 } & & Reactivity & \multirow{2}{*}{ " } & \multirow{2}{*}{40} & \multirow{2}{*}{1050} & \multirow{2}{*}{$\begin{array}{l}\mathrm{N}_{2}+\mathrm{CO}_{2}: 4 \\
\mathrm{CO}_{2}: 5 \sim 75 \%\end{array}$} & \multirow{2}{*}{1} & \multirow{2}{*}{$\mathrm{KOH}: 25$} \\
\hline & & MS I & & & & & & \\
\hline & & MD I & " & 130,150 & 1050 & $\begin{array}{l}\mathrm{N}_{2}+\mathrm{CO}_{2}: 4 \\
\mathrm{CO}^{2}: 25 \sim 100 \%\end{array}$ & $0.5 \sim 2$ & $\mathrm{KOH}: 25$ \\
\hline
\end{tabular}

た炉の中にすみやかに挿入する、コークス充填部が再度 所定温度に到達してから, 所定量の反応ガスを流入し反 応を行なわせた。

コークスー鉱石混合層の実験では，コークス量を一定 に保ち，これと所定重量比の Ore/Coke（以下 O/C と 記す）に相当する焼結鉱とコークスを少量ずつ層状に装 入し，反応を行なわせた．

なお反応率の変化は, 試験目的に応じて反応条件を変 えて行ない，目標反応率を得るようにした。ただ，ア ルカリ添加時はガス化反応をアルカリ分圧のみ一定の条 件で行ない，目標反応率を得た。

コークスの反応率は実験前後の重量差を反応量とし， これの実験前の重量に対する比で求めた．また反応後強 度の評価は, 小型ドラム回転強度指数(以下これをMDI と記す）とマイクロ・ストレングス指数（以下これを MSI と記す)によつて行なつた.

小型ドラム回転強度試験機3) は, 試験高炉で採用して いる粒度範围のコークスについて，反応後強度の代表值 を得るためのものであり，150 $\mathrm{mm} \phi \times 150 \mathrm{~mm}$ の鋼製 ドラム内に $120^{\circ}$ ごとに $30 \mathrm{~mm}$ の羽根 (3枚) を取付 け，これに $20 \mathrm{~mm} \phi$ の鋼球を入れ，回転速度 $10 \sim 200$ rpm間で可変とした. 最適測定条件は，諸因子につき数 水準を選んで予備実験(4)を行ない，鋼球数 25 個，粒度 $9.52 \sim 11.1 \mathrm{~mm}$ の試料 $100 \sim 150 \mathrm{~g}$, 回転速度 $50 \mathrm{rpm}$, 回転時間 $30 \mathrm{~min}$ と決定した.な抬度指数は $+2.38 \mathrm{~mm}$ の重量\%で評価した.

また反応後試料の気孔率は，真比重と見掛比重を測定 し, 気孔率 $=1$ - 見掛比重/真比重の関係から求めた. 真 比重は JIS 法によつて，また見掛比重は水銀置換方式
によつて測定した.

\section{$2 \cdot 2$ 実験条件}

Table 1 に実験条件を一括して示した．実験に供した 試料は試験高炉第 26 次操業で使用した A (良質)， B 劣質）コークスである. 試料粒度は，MDI の測定条件 の制約から 9.52〜12.7 mm に篩い分けしたものを使用 した.なおこの粒度は試験高炉で採用している粒度範囲 の調和平均粒度にほぼ一致している。

Table 1 の MDI 測定の場合には, 試料重量を目標反 応率に応じて 130〜250 g とした。な招目標反応率は， 反応温度，ガス濃度，ガス流量および反応時間を变える ことによつて得るよらにした．ただ，フルカリ添加時 は, アルカリ添加量を $25 \mathrm{~g}$, 反応温度を $1050^{\circ} \mathrm{C}$ 一定 （すなわち，アルカリ分圧一定）とし，ガス濃度，反応 時間のみを変えて目標反応率を得た.

MSI 測定の場合には,アルカリ添加時と無添加時のい ずれも試料重量を $40 \mathrm{~g}$ (層高 $30 \mathrm{~mm}$ ) と量を减らし, 高さ方向の反応率分布をさけるようにした，な扳応率 の変化は, 反応温度を $1050^{\circ} \mathrm{C}$ 一定とし, ガス濃度, 反応時間を任意に变えて行なつた。

アルカリ添加時の反応性試験に供した試料は，そのま ま MSI 測定試料に併用した.なおフルカリ添加時と無 添加時の反応の進行様式の違いを推察するために，反応 後見掛密度，粉率 $(-1 \mathrm{~mm} w \mathrm{t} \%)$,さらに発生粉の実質 的な反応率などを測定した。

また本実験で用いたA，Bュークスの常温に抽す諸 強度指数を Table 2 に示した.な挔表中のドラム指数 $\mathrm{DI}_{1 \mathrm{~b}}^{30}$ はいらまでもなく大塊試料に関するものであり, IDI は新日鉄名古屋方式)によるデータである。この 
Table 2. Strength index of coke (\%).

\begin{tabular}{|c|c|c|c|}
\hline \multicolumn{2}{|c|}{ Kinds of coke } & Coke A & Cokeb B \\
\hline \multicolumn{2}{|c|}{ Porosity } & 45.1 & 47.4 \\
\hline \multicolumn{2}{|c|}{ Gasification ratio for IDI } & 24.8 & 34.6 \\
\hline \multirow{2}{*}{$\stackrel{*}{\stackrel{*}{口}}$} & Befor reaction & 88.8 & 83.6 \\
\hline & After reaction & 63.9 & 45.2 \\
\hline \multicolumn{2}{|r|}{$\mathrm{DI}_{16}^{30 * *}$} & 90.8 & 88.7 \\
\hline \multicolumn{2}{|r|}{$\mathrm{TI}_{25}^{1400}$} & 54.7 & 45.1 \\
\hline \multirow{2}{*}{$\stackrel{\overrightarrow{2}}{\Sigma}$} & $+28 \mathrm{mesh}$ & 54.5 & 43.9 \\
\hline & $+48 \mathrm{mesh}$ & 70.8 & 63.1 \\
\hline \multicolumn{2}{|r|}{ MID } & 82.3 & 75.3 \\
\hline
\end{tabular}

表から明らかなようにBコークスは，別報2にに示したよ らに化学組成以外のすべての点で劣質であることが明り ようである。

\section{3. 実験結果および考察}

\section{1 アルカリ無添加時の反応後強度}

$3 \cdot 1 \cdot 1$ ニークス単味の場合の反応後強度試験

この実験では，反応率と反応後 MDI との関係への反 応温度の影響をも併せて調へるために，意識的に温度を 変えた. Fig. 1 に反応率と反応後 MDI との関係を示 した.これから次のことがわかる.

(1)この実験条件の範囲内では，反応率と反応後 MDI との関係は温度の影響をらけない（A，Bューク スのいずれのデータも温度に関係なく一つの線上によく のつている).

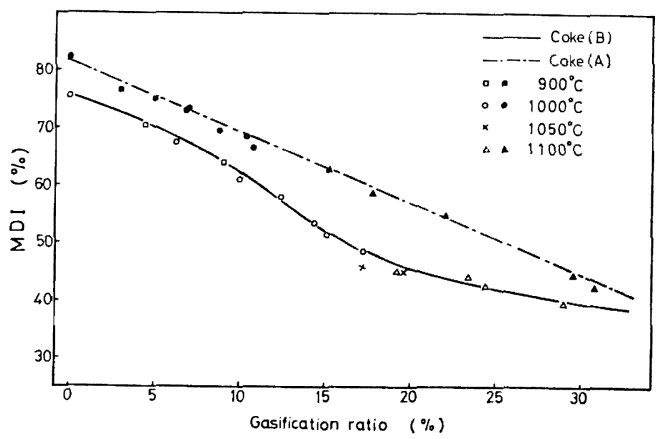

Fig. 1. Relation between gasification ratio and MDI after reaction.
（2）実験範囲内では，同一反応率での反応後強度は

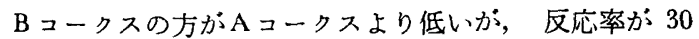
\%程度になると両者の差がなくな.

(3) A ークスでは反応率の増大に伴って強度が直 線的に低下寸るが，Bコークスでは反応率 10\% 近傍で 強度が急低下するのが特徵的である.

な拈この実験で, $30 \%$ 近くまで反応させた試料の肉眼 観察と顕微鏡観察によると, 試験高炉内の残留コークス 中にみられたようなマクロき裂やミクロき裂の発生は全 く認められなかつた.

$3 \cdot 1 \cdot 2$ コークスと鉱石の混合の場合の反応後強度 この実験は，炉内残留コークスの炉壁部が鉱石とコー クスの混合層になつておうりここの部分の劣化がとくに著 しかつたために行なつたものであり，Fig. 2 に/Cの 反応率ならびに反応後 MDI に拉よぼす影響を示した. これによれば, A， Bュークスともに $\mathrm{O} / \mathrm{G}$ の増大に伴 つて，ほぼ同じ割合の反応率上昇と，その反応率の上昇 分にみあつた反応後 MDI の減少がみられ, 両コークス への O/C の影響には差がないことがわかる.

Fig. 3 に Bュークスの $\mathrm{O} / \mathrm{C}$ がO (コークス単位) と 2 の場合における反応率と反応後 MDI におよぼす $\mathrm{CO}_{2}$ 分圧の影響を示した．これによると，O/C の水準がち がつても $\mathrm{CO}_{2}$ 濃度による反応率や反応後 MDI の変化 傾向には差が認められないことがわかる。

Fig. 4 は鉱石の存在が反応率を増大させ，その増大分 だ反応後強度の低下をもたらす以外に，他の特別な劣 化要因をもつかどらかを検討する意味で，O/G の水準 のちがいを度外視して，鉱石混合時の反応率と反応後

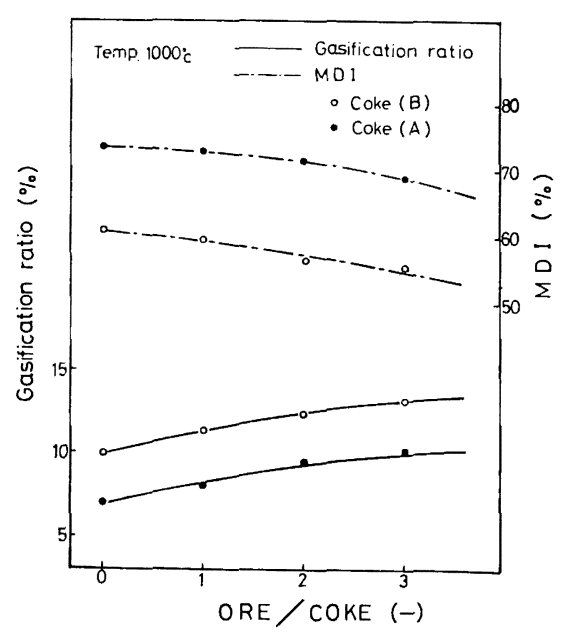

Fig. 2. Effect of ore on gasification ratio and MDI after reaction. 


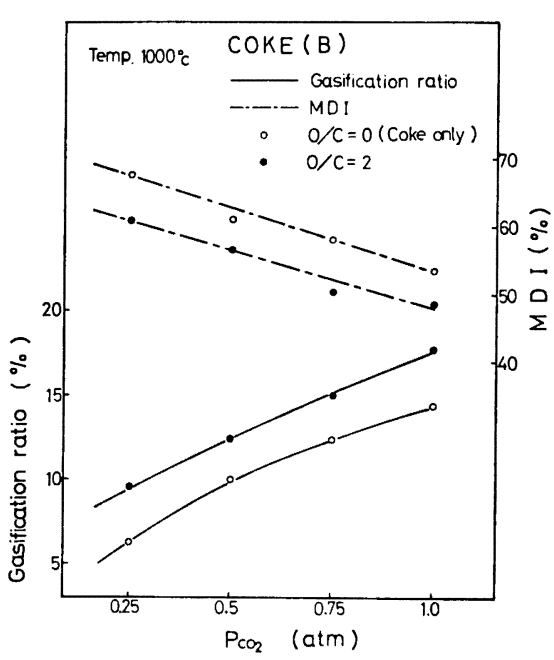

Fig. 3. Influence of ore on relation between $\mathrm{P}_{\mathrm{co} 2}$ and gasification ratio or $\mathrm{MDI}$ after reaction.

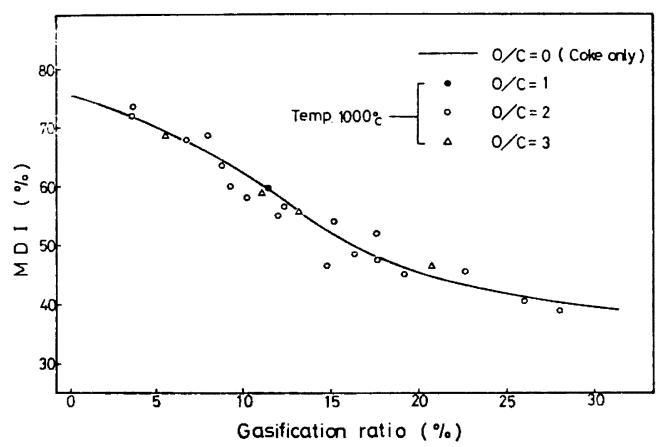

Fig. 4. Relation between gasification ratio and MDI after reaction under the presence of ore.

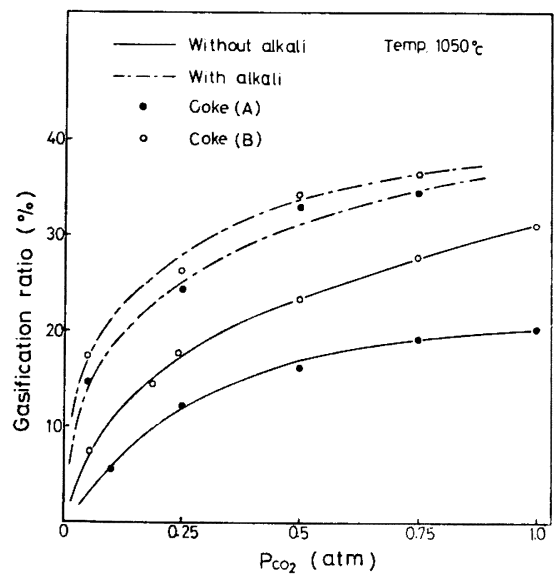

Fig. 5. Influence of alkali addition on reactivity of coke.

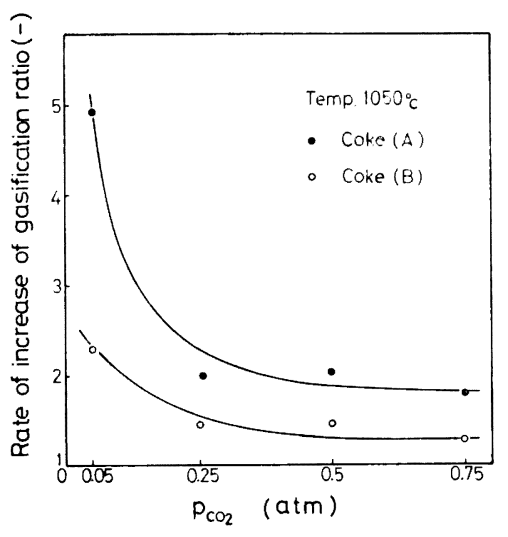

Fig. 6. Increase of gasification ratio by alkali addition.

MDI との関係を, Fig. 1 で得られたュークス単味の関 係曲線上に，Bュークスについてのデータをプロットし たものである.これによると，O/G の相違に関係なく データは, ュークス単味の関係曲線近傍に分布してお り，鉱石の存在は反応率の増大以外の特別の劣化要因之 はならないものと判断される.

\section{2 アルカリ添加時の反応後強度}

$3 \cdot 2 \cdot 1$ コークスの反応性におよぼすフルカリの影響 アルカリ添加時と無添加時の反応率の $P_{\mathrm{CO}_{2}}$ 依存性, さらにその時の反応率上昇の関係を Fig. 5, Fig. 6 に 示した.

Fig. 5 によると，アルカリ無添加時はA， B ュークス の間に明りょらな反応性の差がみられるが，アルカリ添 加時にはA， B ニークスのいずれについてもガス化速度 の増大がみられ，しかもその程度は反応性の低い $\mathrm{A} ュ ー$ クスの方が顕著であるため，両者の反応性の差が小さく なつている. また Fig. 6 によると，アルカリ添加によ る反応率の上昇割合は， $P_{\mathrm{CO}_{2}}$ の低下に伴つて増大し， $P_{\mathrm{CO}_{2}}$ が $0.05 \mathrm{~atm}$ 近傍では 2 (B コークス) 5(A ュー クス）倍の反応率を示している.したがつて，アルカリ の触媒作用による反応性の增大は低 $\mathrm{CO}_{2}$ 濃度でとくに 影著になると推察される.

$3 \cdot 2 \cdot 2$ 反応の進行様式におよほすすフルカリの影響 アルカリの反応の進行様式一の影響を, 反応後気孔率 の変化特性から検討しよらとしたか，Fig.7に示したよ 5に反応後気孔率が反応後見掛密度と直線的な関係を示 すことから，後者の反応後見掛密度の変化から検討する こととし，Fig. 8 にその結果を示した.これから，アル カリ無添加の場合は， A， B ニークスのいずれも反応率 の増大に伴つて反応後見掛密度の低下がみられるが，A コークスの方が著しく, 反応率 $30 \%$ 程度で両者の差が 


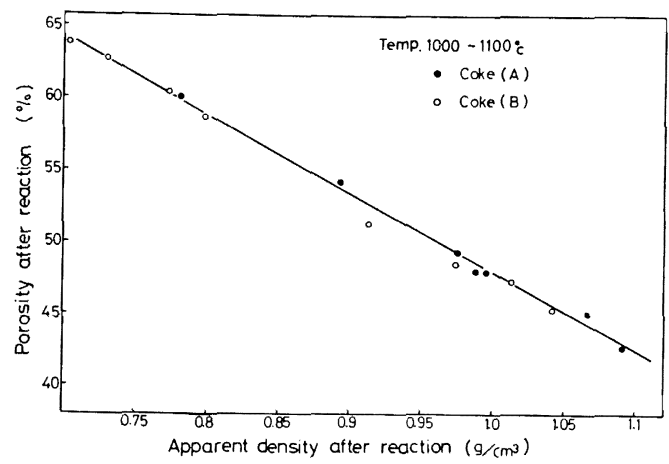

Fig. 7. Relation between apparent density and porosity after reaction.

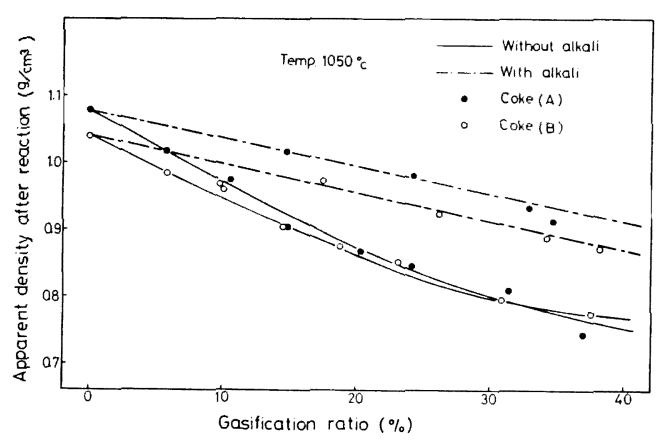

Fig. 8. Influence of alkali addition on relation between gasification ratio and apparent density after reaction.

なくなつている.

一方, アルカリ添加時は, 見掛密度の反応による低下 は直線的でかつゆるやかであり，しかもA， Bュークス の初期見掛密度の差が維持されており, 反応の進行様式 がアルカリ無添加時とでは本質的に異なることを示唆し ている.

すなわち，アルカリ無添加時は反応がュークス粒子の 全容において進行するのに対し, アルカリ添加時はアル カリの触媒作用によつて化学反応速度が大きくなる結 果, 反応がュークス粒子のより表面帯に局限されるよう になること，そしてこの傾向がAコークスにより顕著に 現われることを示していると考えられる.

事実, Fig. 9 に反応による $-1 \mathrm{~mm}$ 粉の発生率を示し たがこれによると粉の発生率はアルカリの添加により 著しく増大すること，しかも Fig. 10 にみられるよう に発生粉の灰分ハランスから求めた粉の奏質的な反応率 は, アルカリ添加によつて低反応率においても著しく高 いことがわかるこれらの事実は，アルカリの添加によ り反応がり表面帯に局限され，この部分における局所

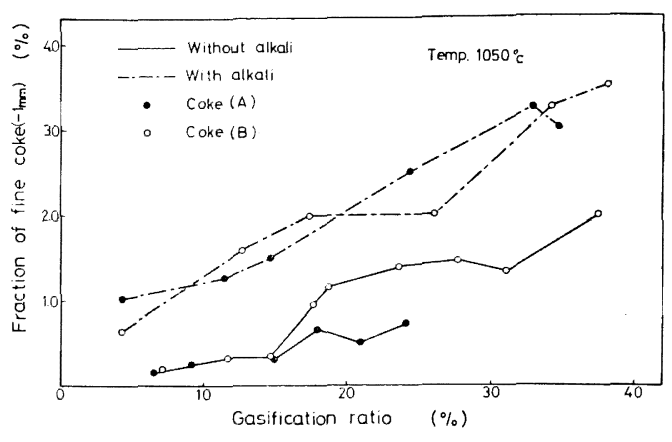

Fig. 9. Relation between gasification ratio and fine coke fraction after reaction.

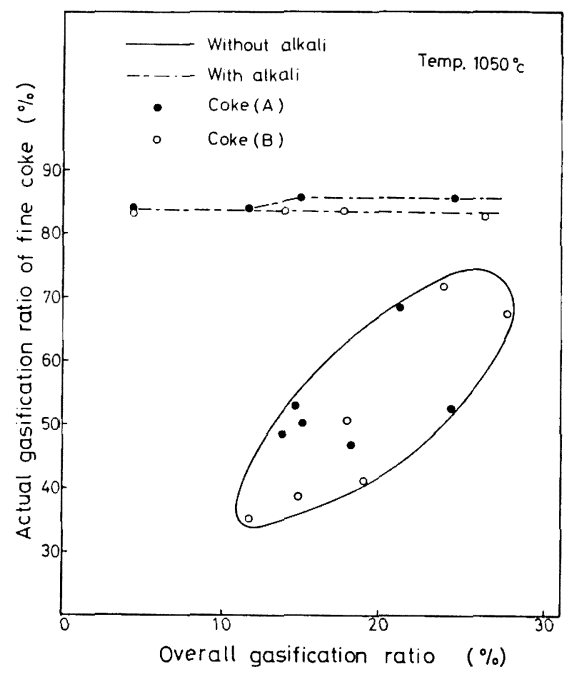

Fig. 10. Relation between overall and actual gasification ratio of fine coke.

的な反応率が著しく上昇することを示している.

またアルカリ無添加時はコークス粒子全体の平均的な 統括反応率（以下これを総括反応率と記す）の増大に伴 つて, 発生粉の実質的な反応率がほぼ正の相関で增大寸 るのに対し，アルカリ添加時は総括反応率に関係なく, ほぼ一定值を示し， A， B ュークスの間にほとんど差が みられない.このことは $\mathrm{CO}_{2}$ ガスとカーボン成分との 反応性が，アルカリ添加時と無添加時とでは異なること を示唆している.

すなわち，アルカリ添加時は，その局所反応帯におい て, カーボンの活性成分拉よび不活性成分を問わず反応 が一様に進行するのに対し，アルカリ無添加時は，カー ボン成分によつて反応が選択的に進行するるのと思われ る.このように考光れば, 気孔率の注添近いコークス は, そのコークスの固有の反応性に差があつても, アル 


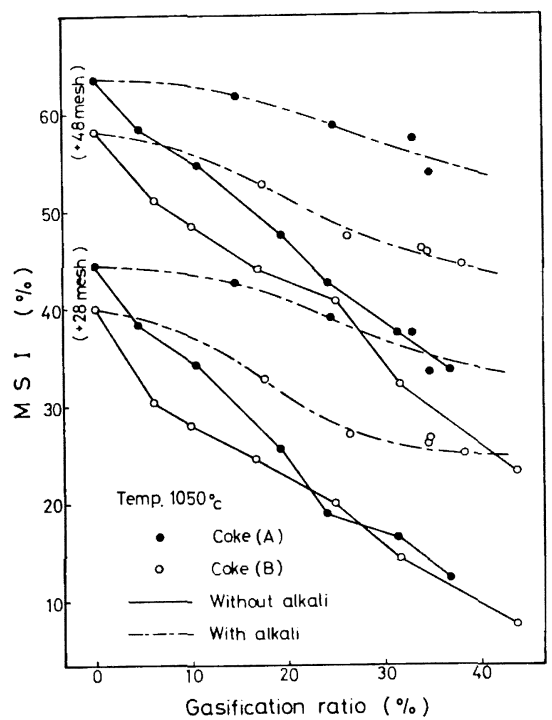

Fig. 11. Relation between gasification ratio and MSI after reaction.

カリの添加によつて反応性の差がなくなるということに なる. Fig. 5 で示されるように, 反応性の低いA スがアルカリの添加によつて，高反応性になり，A， B コークスの反応性の差がなくなつたのはこの予測を裏づ けるものと思われる.

\section{$3 \cdot 2 \cdot 3$ 反応後強度におよぼすアルカリの影響}

Fig. 11 にアルカリ添加時と無添加時の MSI の反応 率による変化を対比して示した。これによると，アルカ リ無添加の場合には，A，Bいずれのコークスについて も MSI は反応率の増大とともに低下寸るが，このさい MSI : + 48 mesh ではA，B コークスの初期差が維持さ れるのに対し，MSI：+28 mesh では反応率 $20 \%$ 程度 で両者の差がなくなる.

一方，アルカリ添加の場合にも，MSI の反応率の増 大に伴ら低下はみられるが，その程度はアルカリ無添加 の場合よりあきらかに小さい。しかも $\mathrm{A}, \mathrm{B}$ 両コークス の MSI の差は反応率の増大とともに払大し，この傾向 は MSI : +48 mesh だけでなく,MSI : +28 mesh につ いても明りょらであり，アルカリ添加時と無添加時とで は， A， Bュークスの MSI の反応による低下特性の間 に顕著な差がみられる。

Fig. 12 は反応後見掛密度と MSI との関係を示した もので, この場合にも A, B ーークスのい゙れもアルカ リ添加時の見掛密度低下に伴う MSI の低下は, 無添加 時にくらべ小さくなるが，この傾向はA Aークスの場合 とくに明りょうである.

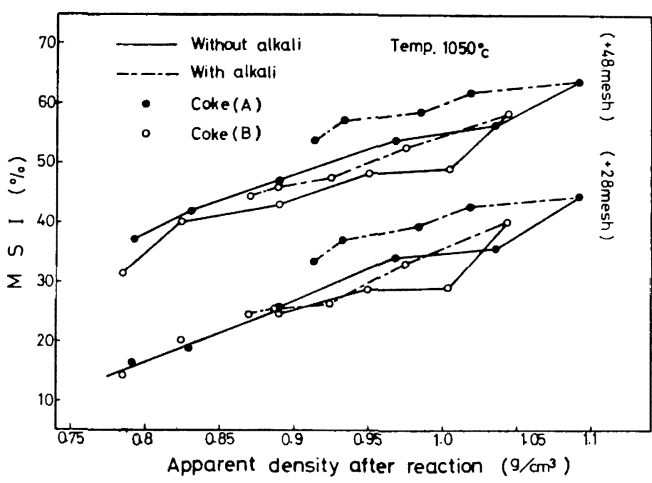

Fig. 12. Relation between apparent density and MSI after reaction.

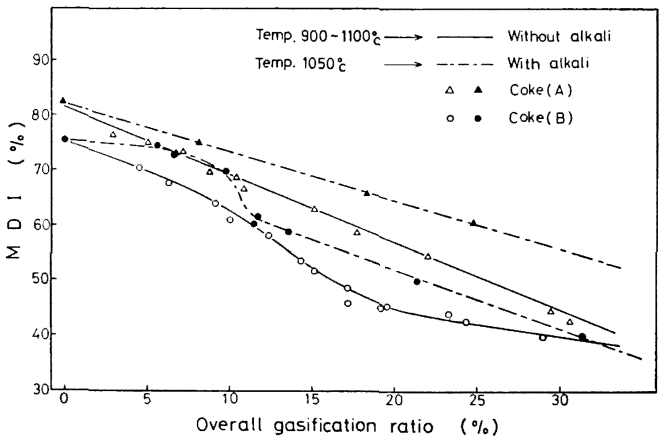

Fig. 13. Relation between overall gasification ratio and MDI after reaction.

これらの結果は，アルカリ添加による反応性の増大 が，反応のコークス粒子表面帯への局限をもたらし，逆 に粒子内部の健全性を保存することになる理論的傾向6) と一致するものである.ささらにこの傾向は気孔率が小さ いために反応帯幅が狭いとみられるA く現われていることを示している.

他方，この効果が B コークスでは余り顕著でないとい ら事実は，A，B両コークスの見掛密度の低下（反応率 の増大）に伴う MSI 低下傾向の差が +28 mesh 指数に ついても明りょらになるといら事実とともに，Bューク スの基質がどの程度ガス化したら粉化するかという「限 界反応率」6) が相対的に低いことを示すもののように思 われる。

このよらにアルカリの存在のもとでは，その触媒作用 による局所高反応率化によつて，又か壮上， A， B両コ ークスのミクロ強度低下率が小さくなると同時に，両者 の強度差は顕著になると考えられるが，Fig. 13 はこの 傾向が MDI のようなマク口強度にも現われることを示 している.すなわち，Bュークスの MDI はアルカリ無 
添加の場合にも，総括反応率 $10 \%$ 近傍で急激に低下寸 る傾向を示すが，この傾向はアルカリの添加によつて極 端に明りようになる。また A, B 雨コークスの強度低下 率はアルカリの添加によつて小さくなるといら様相を示 す一方, 両者の強度差は反応率の增大につれて払大寸る といら点で, 無添加の場合とは異なつている.

MDI 試験は, MSI 試験にくらべて多量の試料を必要 とし, 層高が大きくなる結果, 反応率の層高方向の分布 が著しくなり，それが個々の粒子内での反応率分布と重 なるため, 試駼結果の解釈はむつかしい.しかし MSI 試験の結果に関する上述の所論にてらしてみれば，A， B 両コークスの反応によるマクロ強度低下の差が, 高い (局所)反応率において顕著になるとみることは妥当と思 われる。またBコークスのある総括反応率での MDIの

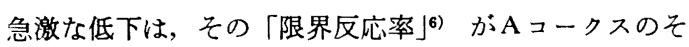
れより本質的に小さいことを示唆するもののように思わ れる。

\section{4. ガス反応による細粒化要因に関する推論}

别報2によると、アルカリ吸着による直接的な劣化 は，Bコークスの著しい劣化の原因になつたとは考兄ら れなかつたが，本実験結果からの推論として，Bコーク スの極端な劣化の（少なくとも一つの）要因はガス化反 応の高反応率化にあつたとみることができる.

事実, 試験高炉内でみられた細粒化ュークスの気孔の 粗大化と MSI が格段に低い值を示したことは, 高い反 応率を意味するものとして，この仮説を支持するものの よらに思われるまをた炉内を循環するアルカリが局所高 反応率化に寄与することは明らかであり，また格段に高 い（実験温度よりは）燃焼带近傍に淤ける温度とそこに 打ける低 $\mathrm{CO}_{2}$ 分圧も同じ効果をるつと考えることがで きる。

\section{5. 総括}

試験高炉第 26 次操業で使用した A，Bコークスにつ いて，アルカリ添加時と無添加時におけるガス化反応に
よる劣化の実験を行ない, 次のような結果を得た。

(1) $\mathrm{A}$ コークスの MDI は反応率の增大に伴つて直 線的に低下寸るが，Bュークスのそれは反応率 $10 \%$ 近 傍で急低下-るるが特徵的である。な扳応率が $30 \%$ 近傍で両者の MDIの差がなくなりこの反応率までは マクロき裂や気孔壁内にミクロき裂の発生は全く認めら れなかつた。

（2） A，Bコークスともに，鉱石の混合制合の増大 に伴って反応率が増大し，その反応率の増大分だけ MDI の低下がみられたが，これ以外の劣化要因は認められな かつた.

（3）反応性の低いコークスは，アルカリの触媒作用 をより顕著にらけ，その結果コークス種による固有の反 応性の差が小さくなる。

（4）アルカリを添加すると，その触媒作用によつて 化学反応速度が大きくなる結果, 反応がコークス粒子の 上り表面帯に局限され，その部分の局所的な反応率が增 大し, 粒子内部の健全性が保存されるために反応後見掛 密度ならびに反応後強度の低下率はアルカリ無添加時に 比べ小さくなる.

（5） B コークスは総括反応率 10\% 近傍で MDI が 急低下寸るが，この傾向はアルカリの添加によつてさら に極端になる．このBコークスの急低下はコークスには 「限界反応率」が存在すること, さらにその「限界反㐫 率」がA ニークスのそれより本質的に小さいことを示唆 するものであり, それが高い反応率によつてBコークス の試験高炉内での極端な劣化を引き起こす一つの要因に なつたものと思われる。

\section{交献}

1) $M$. TAtE, et al.: Trans. ISIJ, 投稿中

2 ) 張 東植, 館 充: 鉄と鋼, 65(1979), p. 479

3 ) 張 東植, 館 充: 学振 54 委-1341 (1975)

4) 張 東植, 館 充: 未発表

5）新日鉄：第６回製鉎部会コークル分科会資料， (1973)

6 ）新日鉄基礎研：第 13 回彆銑部会コークス分科会 資料，(1976) 